\title{
The Influence of Economic Policy Uncertainty and Business Cycles on Fine Wine Prices
}

\author{
Hachmi Ben Ameur ${ }^{1}$. Eric Le Fur ${ }^{2}$ (D) Julien Pillot ${ }^{1}$
}

Accepted: 16 November 2021

(c) The Author(s), under exclusive licence to Springer Science+Business Media, LLC, part of Springer Nature 2021

\begin{abstract}
This study investigates the impact of both economic policy uncertainty (EPU) and business cycles on the fine wine market. We use a nonlinear autoregressive distributed lag model to measure the influence of these two variables on three major Liv-ex indices over the period 2005M01-2020M12. Our results are multiple. First, fine wine prices are relatively unaffected asymmetrically by EPU, while the economic cycle has a more pronounced asymmetric effect, especially in the short run. Second, uncertainty in Europe and the USA affect fine wine prices more than in China. Third, in the short term, fine wine prices react more strongly to changes in business cycles than to uncertainty. Finally, prices of the five first growths of Bordeaux are asymmetrically influenced by EPU, unlike of the rest of the most prestigious Bordeaux wines. The study also has implications for investment. We argue that a strong and professional strategic intelligence watch would help stakeholders in the secondary wine market to improve their returns, especially when European and US wines are involved. While shortrunners should focus on information relative to changes in the business cycle, long-term investors would find it more interesting to closely monitor policy decisions liable to have long-term effects on wine prices (such as taxation, monetary measures...).
\end{abstract}

Keywords Fine wine prices · Uncertainty $\cdot$ Business cycle $\cdot$ Nonlinear ARDL model

\footnotetext{
$凶$ Eric Le Fur

elefur@inseec.com

Hachmi Ben Ameur

hbenameur@inseec.com

Julien Pillot

jpillot@inseec.com

1 INSEEC Grande Ecole, Rue de Vellefaux, 75010 Paris, France

2 INSEEC Grande Ecole, H19 Quai de Bacalan, 33070 Bordeaux, France
}

Published online: 11 January 2022 


\section{Introduction}

Scholars have taken a growing interest in the market for collectibles and real alternative investments since the 1990s (Burton \& Jacobsen, 1999; Le Fur, 2021a, 2021b). Indeed, the weight of these assets in portfolios of high-income households and specific investment funds is expanding (Satchell, 2009). Art, classic cars, coins, rare whiskeys, stamps, and fine wines are the main components of collectible assets held by individual investors (Le Fur, 2018, 2020). Thus, fine wines are valued as they are a popular investment asset (Fogarty, 2010; Storchmann, 2012), a store of value (Bouri, 2014), and have little correlation with traditional investments (Coffman \& Nance, 2009; Kourtis et al., 2012). However, investors in the fine wine market must also factor in specific considerations such as insurance, information asymmetries, emotional bias, intermediary commission, transportation costs, heterogeneity, illiquidity, market segmentation, and specific taxes (Amédée-Manesme et al., 2020; Baumol, 1986; Masset et al., 2021; Outreville \& Le Fur, 2020).

It is now very common for investors to include fine wines in their portfolio as diversification assets. Indeed, according to Masset and Henderson (2010), investors value both their advantageous risk-return profile and their low exposure to financial risk. The London International Vintners Exchange (Liv-ex) indices are used as a benchmark by investors to monitor prices of the most widely sought-after fine wines on the market (Cardebat et al., 2020). It is therefore no surprise that, as for any other alternative financial asset, investors are increasingly interested in obtaining accurate models of fine wine returns and pricing determination (see Le Fur \& Outreville, 2019, for a review of the literature). This has been the focus of several studies in wine economics. These studies are all the more important given that the wine market is global and has recently been impacted by several protectionist decisions and new free-trade agreements. Such policies have implications both on export volumes and on the price of fine wines, and need to be taken into account in the strategies of both investors and producers.

For instance, the seminal work by Krasker (1979) and Jaeger (1981) explored how stored wines perform compared to riskless assets such as treasury bonds. Further studies have highlighted the diversification benefits of fine wines in investors' portfolios, both in terms of return expectations and risk reduction (e.g., Sanning et al., 2008; Kourtis et al., 2012; Chu, 2014; Le Fur et al., 2016; Faye et al., 2015; Aytac and Mandou, 2016). Indeed, most empirical studies provide evidence that fine wine can be considered as a riskless asset, and may perform better than other collectibles assets (Ben Ameur \& Le Fur, 2020; Dimson et al., 2015).

A great deal of academic research currently focuses on the macroeconomic determinants of fine wine prices. Jiao (2017), for instance, shows that the price of fine wine is particularly attuned to the rising demand from emerging countries and thus to the way the USA appreciates this asset in real terms (e.g., relative to emerging market currencies). Jiao (2017) also notes that as the market for fine wine becomes more and more financialized, fine wine pricing is increasingly affected by other factors such as real interest rates, investment funds growth, and money supply. These findings are not surprising as they are in line with those of other scholars. For instance, the impact of Chinese demand on fine wine prices was underscored by Anderson and Wittwer (2013) 
and Masset et al. (2016). More recently, Cardebat and Figuet (2019) found a strong correlation between real exchange rates and the pricing of fine wine.

Another set of studies investigates how different kinds of uncertainty affect the pricing of fine wine and, more broadly, the performance of investors' portfolios. Wine-growing weather is probably one of the greatest uncertainties that affect both production volume and quality. Ashenfelter (2008) argues that much of the variability in prices across vintages in a portfolio of Bordeaux Chateau Wines is explained by the weather in which a vintage is grown. More recently, Hekimoglu et al. (2017) explored how investors or wine distributors can determine the optimal selection of bottled wine and wine futures in conditions of weather and market uncertainty. Expected returns are greater when businesses invest in wine futures - though a riskier asset—rather than bottled wine. Noparumpa et al. (2015) reached the same conclusion. They conducted an empirical study involving data collected from Bordeaux wineries engaging in wine futures and found that the wine futures market offers a sizable financial benefit to winemakers.

The business climate is a second form of uncertainty investors must deal with. How the fine wine indices perform during crisis periods is a point of concern, for instance. Following the pioneer work of Bouri (2014), Masset and Weisskopf (2018) provided evidence that fine wines offer valuable alternative investments during equity market downturns.

However, the literature in wine economics provides few insights into how Economic Policy Uncertainties (EPU hereafter) or business cycles ( $\mathrm{BC}^{1}$ hereafter) in China, Europe and the USA influence fine wine prices. This is even more surprising given that EPU is considered to present an important risk factor for equities (Brogaard \& Detzel, 2015), as well as a driver of prices of many investment assets such as housing (Antonakakis et al., 2015), gold (Jones and Sacklay, 2016), and oil (Balcilar et al., 2017).

Scholars have recently turned their attention to how specific geopolitical events such as Brexit (Anderson \& Wittwer, 2018) or new trade agreements (Dimson et al., 2015 ) - have impacted the prices of fine wines. While valuable and necessary, such research is unlikely to encompass the full spectrum of uncertainty and instability factors that affect the markets. The measurement of EPU is specifically designed to give investors a comprehensive monthly analysis of all the uncertainties flowing from government announcements and policies as reported in the media (Baker et al., 2016). In addition, EPU is more strongly correlated with measures of financial volatility than with consumers' assessment of uncertainty, in other words, the media place far greater weight on the financial sector than on the economic issues of consumers (Lolic et al., 2021). Openly accessible on major sites such as Reuters or Bloomberg, EPU is advantageous in two ways. First, as mentioned above, it is an efficient legislative and regulatory business intelligence tool that encompasses every policy uncertainty arising from government decisions, such as new market regulations or changes in tax and monetary policies. Second, it is a valid proxy of the business climate since it provides a monthly report on how markets behave — and could behave in the near future-with respect to the uncertain repercussions of most recent government decisions.

\footnotetext{
1 The basic neoclassical model is presented in King et al. (2002).
} 
Assessing the influence of EPU and BC on real alternative investment assets-such as fine wines - is very helpful per se. In a post-Covid 19 context of sudden economic downturn and radical uncertainty (in which governments across the globe have taken exceptional measures with largely unpredictable short and long-term effects), all this becomes mandatory. Applied to our topic, such research could give investors and distributors very helpful insights on how they should behave with regard to changes in EPU levels.

Shankar and Francis (2020) published the first attempt to assess the impact of EPU on fine wine prices. To this end, they used Prais-Winsten and Cochrane-Orcutt regressions to highlight potential (contemporaneous) correlations between changes in leading wine market EPU levels (China, France, Germany, UK and USA) and several Liv-ex indices. ${ }^{2}$ The authors' findings were threefold. First, they found significative negative correlation between EPU in most of the leading wine markets and most of the Liv-ex indices. Second, the authors' cross-country examination showed that French wines behave distinctively to changes in EPU levels, as they are significantly more reactive than fine wines from other regions. Third, France's EPU has no significative influence on Liv-ex indices. However, Dagenais (1994) showed that this procedure may imply fewer unreliable and misleading results, particularly when the independent variables contain measurement errors. The purpose of this paper is to investigate the impact of changes in EPU and BC levels on the prices of fine wines. In addition, in comparison with Shankar and Francis' study, we used the nonlinear auto-regressive distributed lag (NARDL) from Shin et al. (2014). This approach allowed us to observe the nonlinearity and asymmetry over the short and long runs for the relation between these economic factors and fine wine prices.

The NARDL approach allowed us to take the impact of shocks into account with different time horizons. Indeed, a change in EPU and/or BC can lead to variation in the wine market beyond the question of time. The change in wine market time series can be reflected immediately but can also be spread over several periods. The NARDL approach has several advantages compared to other well-known methods in the literature. First, it can be used in various cases, even if the regressors are not integrated of the same order: the regressors can be I(1) and /or I(0). Second, this approach allows for different optimal lags at the variable level. Third, Haug (2002) showed that this approach is relatively more efficient for small samples compared to Johansen and Juselius's cointegration methodology.

Our results are manifold. First, fine wines are asymmetrically relatively unaffected by EPU. On the other hand, the economic cycle has a more pronounced asymmetric effect on the price of fine wines, essentially in the short run. Fine wines are also more affected by uncertainty and the business cycle in Europe and the United States than in China. We also noted that the price of fine wines reacts more rapidly in the short term to changes in business cycles than to uncertainty. Finally, prices of the most prestigious Bordeaux are not asymmetrically influenced by EPU and virtually not at all by BC, unlike the five first growths of Bordeaux, especially in the short term. Our paper contributes to the academic literature in two ways. First, it offers a better

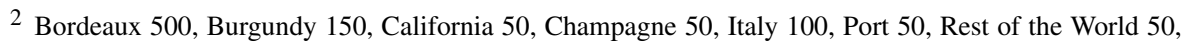
and Rhone 100.
} 
understanding of the determinants of fine wine prices. Second, to our knowledge, it is the first paper to study both the influence of uncertainty and business cycles on fine wine prices.

The rest of the paper is organized as follows: Sect. 2 presents the methodology, while the data is displayed in Sect. 3. We detail the results in Sect. 4, which are then discussed in Sect. 5. Section 6 concludes.

\section{Methodology}

This paper investigates the impact on fine wine prices of Economic Policy Uncertainty (EPU) and Business Cycles (BC) in the American, Chinese, and European markets. We use the nonlinear auto-regressive distributed lag (NARDL) approach introduced by Shin et al. (2014). The NARDL approach allows us to consider nonlinearity and asymmetry over the short run and the long run for the relationship between these economic factors and fine wine prices.

First, the linear auto-regressive distributed lag (ARDL) is as follows:

$$
\begin{aligned}
& \Delta \text { Wine }_{t}^{j}=\alpha_{0}+\sum_{i=1}^{P} \alpha_{1} \Delta \text { wine }_{t-i}^{j}+\sum_{i=1}^{q} \alpha_{2} \Delta E P U_{t-1}^{c}+\theta_{1} \text { wine }_{t-1}^{j}+\theta_{2} E P U_{t-1}^{c}+\varepsilon_{t} \\
& \Delta \text { Wine }_{t}^{j}=\alpha_{0}+\sum_{i=1}^{P} \alpha_{1} \Delta \text { wine }_{t-i}^{j}+\sum_{i=1}^{q} \alpha_{2} \Delta C P I_{t-1}^{c}+\theta_{1} \text { wine }_{t-1}^{j}+\theta_{2} C P I_{t-1}^{c}+\varepsilon_{t}
\end{aligned}
$$

where Wine $e_{t}^{j}$ represents the log prices of the wine series, and $J$ is the indicator for the Liv-ex 50, Liv-ex 100, and Liv-ex Fine Wine Investables, respectively.E PU ${ }^{c}$ is the indicator of Economic Policy Uncertainty for China, Europe, and the USA. $C P I^{c}$ is the business cycle indicator for China, Europe, and the USA. $\alpha_{1}$ is the autoregressive parameter. The $\theta_{1}$, and $\theta_{2}$ parameters allow us to measure the longrun dynamic relationships. $p$ and $q$ are the optimal lag lengths for the dependent and independent variables, respectively. $\varepsilon_{t}$ is an i.i.d. process with zero mean and finite variance. Equation (1) presents the ARDL model for fine wine prices with EPU measures and Eq. (2) with BC measures. The inclusion of positive and negative partial sum decompositions in the linear ARDL Eqs. (1) and (2) allow us to take asymmetric effects in the short-run and the long-run into account.

Equation (3) presents the NARDL model for fine wine prices, including the EPU measure:

$$
\begin{aligned}
\Delta \text { Wine }_{t}^{j}= & \alpha_{0}+\theta_{1} \text { wine }_{t-1}^{j}+\gamma^{+} E P U_{t-1}^{c,+}+\gamma^{-} E P U_{t-1}^{c,-}+\sum_{i=1}^{P} \alpha_{1} \Delta \text { wine }_{t-i}^{j} \\
& +\sum_{i=1}^{q}\left(\beta_{i}^{+} \Delta E P U_{t-i}^{c,+}+\beta_{i}^{-} \Delta E P U_{t-i}^{c,-}\right)+\varepsilon_{t}
\end{aligned}
$$


where, $E P U_{t}^{c,+}$ and $E P U_{t}^{c,-}$ are the partial sums of positive and negative changes in $E P U_{t}^{c}$ defined as follows:

$$
\left\{\begin{array}{l}
E P U_{t}^{c,+}=\sum_{i=1}^{t}\left(\Delta E P U_{t}^{c,+}\right)=\sum_{j=1}^{t} \max \left(\Delta E P U_{t}^{c}, 0\right) \\
\left.E P U_{t}^{c,-}=\sum_{i=1}^{t}\left(\Delta E P U_{t}^{c,-}\right)\right)=\sum_{j=1}^{t} \min \left(\Delta E P U_{t}^{c}, 0\right)
\end{array}\right.
$$

Equation (4) presents the NARDL model for fine wine prices, including the BC measure:

$$
\begin{aligned}
\Delta \text { Wine }_{t}^{j}= & \alpha_{0}+\theta_{1} \text { wine }_{t-1}^{j}+\gamma^{+} B C_{t-1}^{c,+}+\gamma^{-} B C_{t-1}^{c,-} \\
& +\sum_{i=1}^{P} \alpha_{1} \Delta w_{i n e}^{j} e_{t-i}+\sum_{i=1}^{q}\left(\beta_{i}^{+} \Delta B C_{t-i}^{c,+}+\beta_{i}^{-} \Delta B C_{t-i}^{c,-}\right)+\varepsilon_{t}
\end{aligned}
$$

where, $B C_{t}^{c,+}$ and $B C_{t}^{c,-}$ are the partial sums of positive and negative changes in $B S_{t}^{c}$, defined as follows:

$$
\left\{\begin{array}{l}
B C_{t}^{c,+}=\sum_{i=1}^{t}\left(\Delta B C_{t}^{c,+}\right)=\sum_{j=1}^{t} \max \left(\Delta B C_{t}^{c}, 0\right) \\
\left.B C_{t}^{c,-}=\sum_{i=1}^{t}\left(\Delta B C_{t}^{c,-}\right)\right)=\sum_{j=1}^{t} \min \left(\Delta B C_{t}^{c}, 0\right)
\end{array}\right.
$$

For Eqs. (3) and (4), $\gamma^{+}$and $\gamma^{-}$allow us to consider the long-run asymmetry. The positive and negative long-run coefficients are measured as follows: $L^{+}=\frac{-\gamma^{+}}{\theta_{1}}$ and $L^{-}=\frac{-\gamma^{-}}{\theta_{1}}$. The parameters $\beta_{i}^{+}, \beta_{i}^{-}$are associated with the shortrun asymmetry.

The asymmetrical impact over the long-run and/or the short-run of EPU and BC measures on fine wine prices is empirically tested using the parametric Wald test. This test is based on the weighted distance between the unrestricted estimate and its hypothesized value under the null hypothesis. The null hypothesis for the long-run symmetry $H_{0}$ is defined as $\gamma^{+}=\gamma^{-}$, and tested against the alternative hypothesis $H_{1}$ of long-run asymmetry. The null hypothesis for the short-run $H_{0}$ is defined as $\beta_{i}^{+}=\beta_{i}^{-}$, and tested against the alternative hypothesis $H_{1}$ of short-run asymmetry. The optimal model between the following four specifications to measure the impact of EPU and BC on fine wine prices is validated using the Wald test.

First specification: for both the long-run symmetry and the short-run symmetry, the $H_{0}$ cannot be rejected. In this case, the optimal model is the linear ARDL model defined in Eqs. (1) and (2) for the impacts of EPU and BC measures respectively.

Second specification: $H_{0}$ is rejected for both the long-run symmetry and the shortrun symmetry. In this case, EPU and BC measures have asymmetrical impacts with long-run and short-run asymmetry on the wine series. These models are defined in Eqs. (3) and (4). 


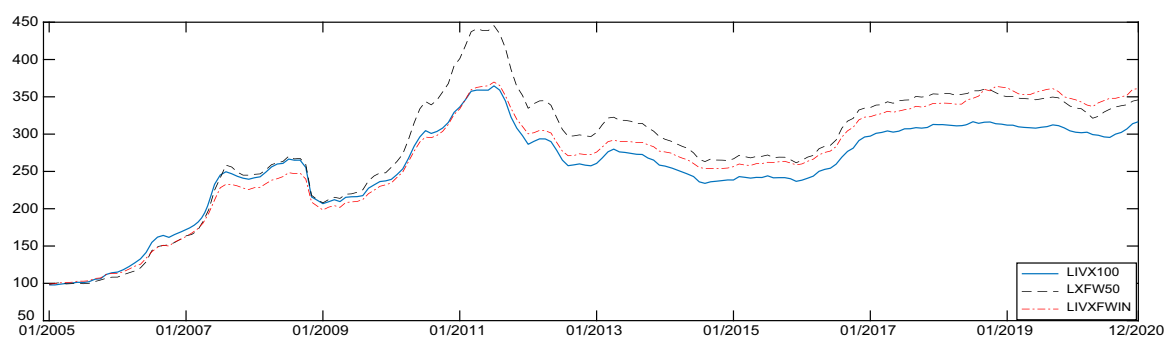

Fig. 1 Wine index series

Third specification: the null hypothesis $H_{0}$ is rejected for the short-run symmetry and cannot be rejected for the long-run symmetry. In this case, the NARDL model is expressed with only the short-run asymmetry estimated by the parameters $\beta_{i}^{+}$and $\beta_{i}^{-}$.

Fourth specification: the null hypothesis $\mathrm{H}_{0}$ is rejected for the long-run symmetry and cannot be rejected for the short-run symmetry. The NARDL model is expressed with only the long-run asymmetry estimated by the parameters $\gamma^{+}$and $\gamma^{-}$.

\section{Data}

The wine market data comes from the Liv-ex platform. ${ }^{3}$ This company, founded in 2000 by two London-based stockbrokers, has been the world's leading fine wine exchange for many years. The platform publishes the actual prices at which more than 16,000 fine wines are traded by over 530 merchants based in over 40 countries. The exchanges represent approximately $95 \%$ of global fine wine sales and are restricted to professional buyers and sellers. Liv-ex also publishes indices divided into major and regional indices. ${ }^{4}$ In our paper, we selected three of the major indices that are most representative of the global market: the Fine Wine 50, the Fine Wine 100, and the Fine Wine Investables. These indexes are reviewed by committee on a quarterly basis. The Liv-ex Mid Price is calculated by finding the midpoint between the current highest bid price and the lowest offer price on the Liv-ex trading platform as indicated on the Liv-ex website. Likewise, the Fine Wine 100 represents the price movement of 100 of the most desirable fine wines on the secondary market. The Fine Wine Investables includes 24 leading Bordeaux red wines which date back to the 1982 vintage and are chosen on the basis of their Robert Parker score. Figure 1 reports the wine index series for the period January 2005-December 2020. The indices were available in base 100 in January 2005. This figure shows that the three indices have progressed evenly over the period in question. There is an initial phase of significant increase until 2012, punctuated by a decrease in 2009. Then, there is a second phase of strong decline at first followed by slight decline until 2016. Finally, a third phase is characterized by a gradual increase until 2020. The Covid-19 pandemic did not impact the indices.

\footnotetext{
3 www.liv-ex.com.

4 For example, Liv-ex Bordeaux 500, Liv-ex Fine Wine 1000, Bordeaux Legends 40, Burgundy 150, Champagne 50, Rhone 100, Italy 100, Rest of the world 60.
} 
To measure the monthly EPU for China, Europe, and the US (Fig. 2), we used Baker et al. (2016)'s indices of economic policy uncertainty. The indices are based on three components. The first is determined from a count of newspaper articles including terms related to policy uncertainty. The second allows us to take into account uncertainty about future changes in the tax code, and the last examines uncertainty about fiscal and monetary policy by considering the dispersion of economic forecasts of the CPI and government spending. The Monthly Business Cycle data (Fig. 3) come from the OECD website using the composite leading indicator (CLI). As presented on the OECD website, CLI "provides early signals of turning points in business cycles showing fluctuation of the economic activity around its long-term potential level. CLIs show short-term economic movements in qualitative rather than quantitative terms."

Table 1 displays the descriptive statistics for all series. The Fine Wine Investables shows the highest return in mean as well as the highest risk. We can also note significant asymmetry and a negative skewed distribution for all the wine indexes. The normality hypothesis is rejected for all wine indexes by the Jarque-Bera test.

Table 2 presents the results of the unit root tests. We used the augmented DickeyFuller (ADF) and Philips-Perron (PP) tests to assess the integration order of the series (Dickey and Fuller, 1979; Phillips and Perron, 1988). Table 2 shows that the Liv-ex 50, Liv-ex Wine Investables, EPU-China, EPU-Europe, BC-Europe, and BC-USA are identified as $I(1)$ at the probability level of $5 \%$, suggesting that the necessary conditions for applying the NARDL approach are satisfied.

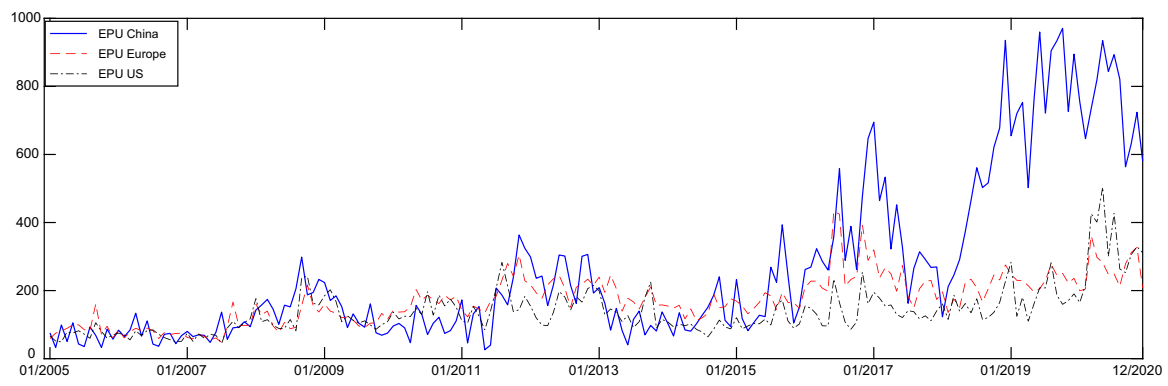

Fig. 2 EPU indices for China, Europe, and the USA

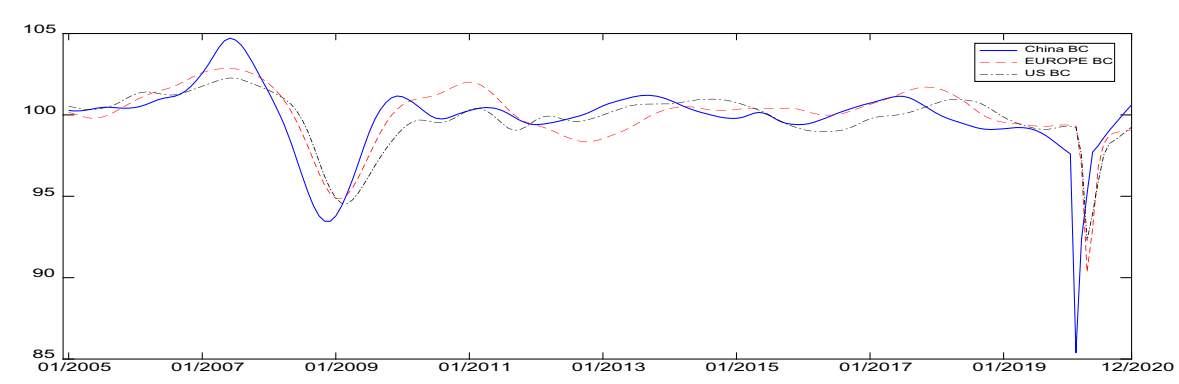

Fig. 3 BC indices for China, Europe, and the USA 


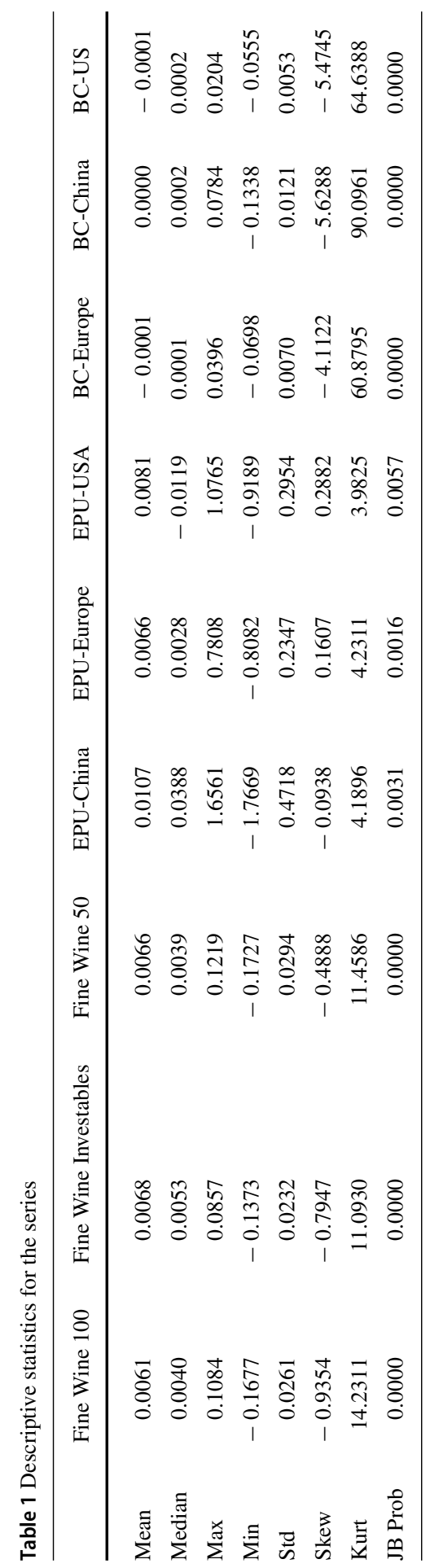


Table 2 Unit root tests

\begin{tabular}{|c|c|c|c|c|}
\hline \multirow[t]{2}{*}{ Variables } & \multicolumn{2}{|l|}{$\mathrm{ADF}$} & \multicolumn{2}{|l|}{ PP } \\
\hline & Log levels & Log difference & Log levels & Log difference \\
\hline Fine Wine 50 & $-2.6840^{*}$ & $-6.3040^{* * *}$ & $-2.7749^{*}$ & $-6.2516^{* * *}$ \\
\hline Fine Wine 100 & $-3.1701^{* *}$ & $-6.4051^{* * *}$ & $-3.1356^{* *}$ & $-6.3613^{* * *}$ \\
\hline Fine Wine Investables & $-2.8271^{*}$ & $-6.1319^{* * *}$ & $-2.8348^{*}$ & $-6.1006^{* * *}$ \\
\hline EPU-China & $-2.5816^{*}$ & $-17.8735^{* * *}$ & $-2.6881^{*}$ & $-24.6719^{* * *}$ \\
\hline EPU- Europe & $-2.6470^{*}$ & $-11.9748^{* * *}$ & $-2.6249^{*}$ & $-28.9107^{* * *}$ \\
\hline EPU- USA & $-3.6947^{* * *}$ & $-12.0236^{* * *}$ & $-4.6436^{* * *}$ & $-35.2009^{* * *}$ \\
\hline BC-China & $-3.8752^{* * *}$ & $-16.4778^{* * *}$ & $-3.8780^{* * *}$ & $-16.4850^{* * *}$ \\
\hline BC-Europe & $-2.7290^{*}$ & $-11.1297^{* * *}$ & $-2.8211^{*}$ & $-9.8692^{* * *}$ \\
\hline $\mathrm{BC}-\mathrm{USA}$ & $-2.8363^{*}$ & $-9.8190^{* * *}$ & $-2.7203^{*}$ & $-9.5300^{* * *}$ \\
\hline
\end{tabular}

* denotes significance at the $10 \%$ level

** denotes significance at the $5 \%$ level and ${ }^{* * *}$ denotes significance at the $1 \%$ level

\section{Results}

First, we tested for long- and short-run asymmetry in the relationship between fine wine prices and uncertainty as well as business cycles. Table 3 shows that the Wald test rejects the null hypothesis of a symmetric relationship between EPU and the Fine Wine 50 (Europe and USA); between EPU and the Fine Wine 100 (Europe); between BC and the Fine Wine 50 (China and USA); between BC and the Fine Wine 100 (China, Europe, and the USA); and between BC and the Fine Wine Investables (USA). Among the Liv-ex indices asymmetrically related to EPU, short-run asymmetric effect is as frequent as long-run. Among Liv-ex indices asymmetrically related to BC, short-run asymmetric effect is more frequent than long-run (5 versus 2). These findings show that EPU and BC shocks result in differing fine wine price reactions according to the region.

Table 4 describes the short- and long-run asymmetric dynamic interactions of fine wine prices with EPU. Regarding the short-run symmetry, the Fine Wine 50 has no adjustments to EPU shocks. Fine Wine 100 has negative lag 2 adjustments to American shocks $(-0.0112)$. Fine Wine Investables has negative lag 1 adjustments to European $(-0.0118)$ and American shocks $(-0.0093)$. Consistent with the Wald test, the Fine Wine 100 and Fine Wine Investables have no significant short-run asymmetric adjustments to EPU shocks. Conversely, the Fine Wine 50 has negative adjustments to European positive shocks $(-0.062)$ and European negative shocks $(-0.0173)$. The Fine Wine 50 also has positive adjustments to American positive shocks (0.0231 in lag 1).

We observe that $\theta_{2}$, which measures the long-run symmetry, is insignificant for the three fine wine indices. The reported impacts $L^{+}\left(L^{-}\right)$of positive (negative) uncertainty shocks are negative and significant at the $5 \%$ level between Europe and the Fine Wine 100, and between the USA and the Fine Wine 50. The long-run adjustment following 
Table 3 Results of long and short-run symmetry tests (with the Wald test)

\begin{tabular}{|c|c|c|c|c|}
\hline $\begin{array}{l}\text { Dependent } \\
\text { variable }\end{array}$ & Independent variable & Long-run & Short-run & $\begin{array}{l}\text { The corresponding } \\
\text { best-fit model }\end{array}$ \\
\hline \multirow[t]{6}{*}{ Fine Wine 50} & EPU-Europe & $\begin{array}{l}2.4624 \\
(0.1184)\end{array}$ & $\begin{array}{l}4.3594 * * \\
(0.0382)\end{array}$ & $\begin{array}{l}\text { NARDL, short-run } \\
\text { asymmetry }\end{array}$ \\
\hline & EPU-China & $\begin{array}{l}0.0419 \\
(0.8379)\end{array}$ & $\begin{array}{l}2.1531 \\
(0.1191)\end{array}$ & ARDL \\
\hline & EPU-USA & $\begin{array}{l}4.1526 * * \\
(0.0362)\end{array}$ & $\begin{array}{l}4.0949 * * \\
(0.0462)\end{array}$ & $\begin{array}{l}\text { NARDL, long-run and } \\
\text { short-run asymmetries }\end{array}$ \\
\hline & BC-Europe & $\begin{array}{l}0.2214 \\
(0.6385)\end{array}$ & $\begin{array}{l}0.6385 \\
(0.8788)\end{array}$ & ARDL \\
\hline & BC-China & $\begin{array}{l}0.3124 \\
(0.5769)\end{array}$ & $\begin{array}{l}3.2361 * * \\
(0.0416)\end{array}$ & $\begin{array}{l}\text { NARDL, short-run } \\
\text { asymmetry }\end{array}$ \\
\hline & BC-USA & $\begin{array}{l}0.8881 \\
(0.3472)\end{array}$ & $\begin{array}{l}4.3620 * * \\
(0.0381)\end{array}$ & $\begin{array}{l}\text { NARDL, short-run } \\
\text { asymmetry }\end{array}$ \\
\hline \multirow[t]{6}{*}{ Fine Wine100 } & EPU-Europe & $\begin{array}{l}4.1979 * * \\
(0.0419)\end{array}$ & $\begin{array}{l}0.5664 \\
(0.4526)\end{array}$ & $\begin{array}{l}\text { NARDL, long-run } \\
\text { asymmetry }\end{array}$ \\
\hline & EPU-China & $\begin{array}{l}0.0482 \\
(0.8264)\end{array}$ & $\begin{array}{l}1.7734 \\
(0.1727)\end{array}$ & ARDL \\
\hline & EPU-USA & $\begin{array}{l}0.1674 \\
(0.6829)\end{array}$ & $\begin{array}{l}0.6715 \\
(0.4136)\end{array}$ & ARDL \\
\hline & BC-Europe & $\begin{array}{l}6.1722 * * \\
(0.0139)\end{array}$ & $\begin{array}{l}6.1395 * * * \\
(0.0027)\end{array}$ & $\begin{array}{l}\text { NARDL, long-run and } \\
\text { short-run asymmetries }\end{array}$ \\
\hline & BC-China & $\begin{array}{l}3.8976 * * \\
(0.0495)\end{array}$ & $\begin{array}{l}2.7960 \\
(0.1063)\end{array}$ & $\begin{array}{l}\text { NARDL, long-run } \\
\text { asymmetry }\end{array}$ \\
\hline & BC-USA & $\begin{array}{l}0.8973 \\
(0.3448)\end{array}$ & $\begin{array}{l}5.6969 * * \\
(0.0180)\end{array}$ & $\begin{array}{l}\text { NARDL, short-run } \\
\text { asymmetry }\end{array}$ \\
\hline \multirow[t]{6}{*}{$\begin{array}{l}\text { Fine Wine } \\
\text { Investables }\end{array}$} & EPU-Europe & $\begin{array}{l}2.6129 \\
(0.1077)\end{array}$ & $\begin{array}{l}1.3175 \\
(0.2526)\end{array}$ & ARDL \\
\hline & EPU-China & $\begin{array}{l}0.0995 \\
(0.7527)\end{array}$ & $\begin{array}{l}0.2344 \\
(0.6289)\end{array}$ & ARDL \\
\hline & EPU-USA & $\begin{array}{l}1.4710 \\
(0.2268)\end{array}$ & $\begin{array}{l}0.2758 \\
(0.6001)\end{array}$ & ARDL \\
\hline & BC-Europe & $\begin{array}{l}0.5940 \\
(0.4419)\end{array}$ & $\begin{array}{l}2.6086 \\
(0.1080)\end{array}$ & ARDL \\
\hline & BC-China & $\begin{array}{l}1.2257 \\
(0.2697)\end{array}$ & $\begin{array}{l}2.9204 \\
(0.1092)\end{array}$ & ARDL \\
\hline & BC-USA & $\begin{array}{l}1.1899 \\
(0.2768)\end{array}$ & $\begin{array}{l}5.1925 * * \\
(0.0239)\end{array}$ & $\begin{array}{l}\text { NARDL, short-run } \\
\text { asymmetry }\end{array}$ \\
\hline
\end{tabular}

The number in brackets are $p$-values

$* * *, * *$, and $*$ indicate rejection of the null hypothesis of asymmetry at the $1 \%, 5 \%$, and $10 \%$ levels 


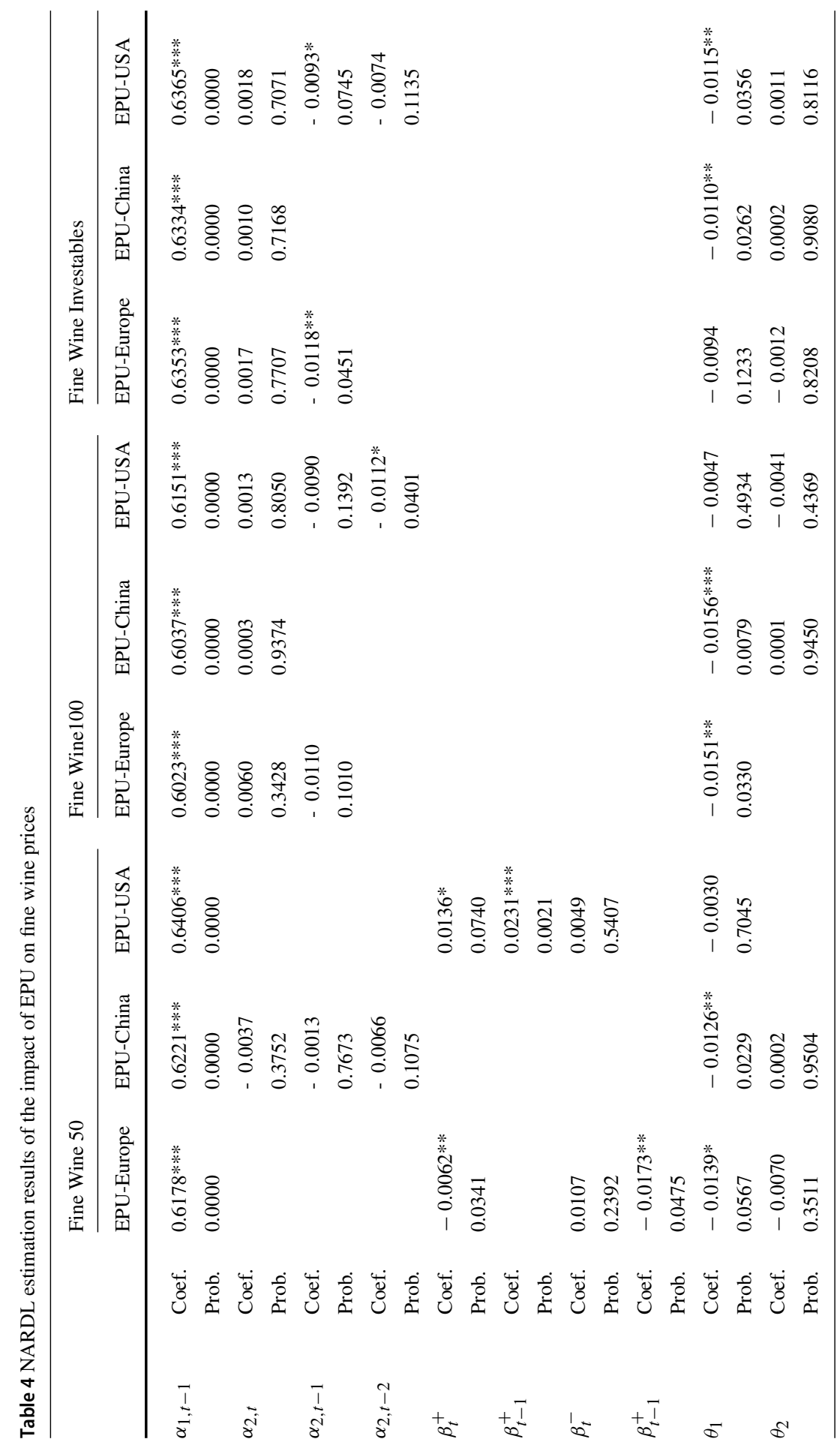




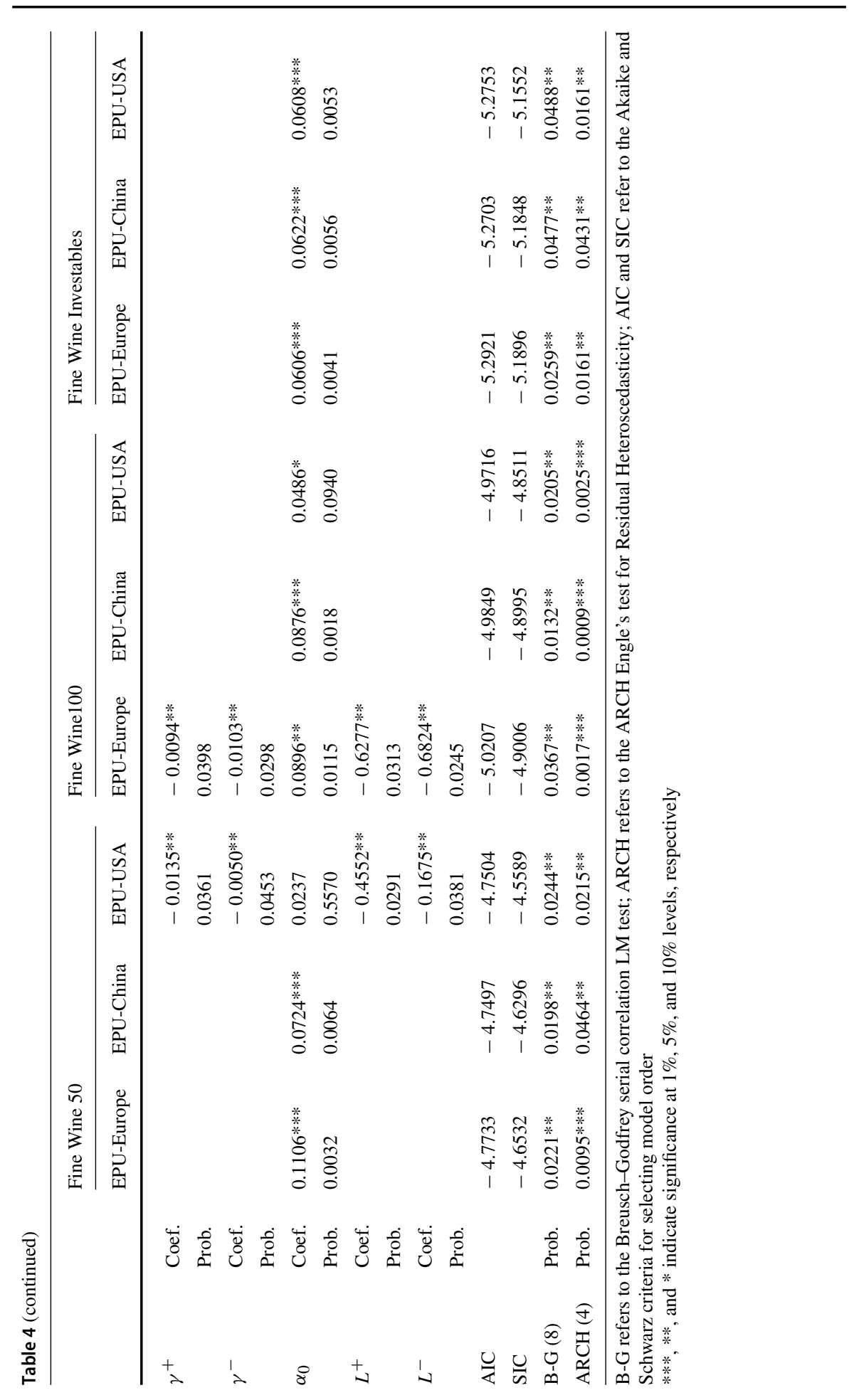


a negative uncertainty shock exceeds that following a positive shock for the Fine Wine 100. In contrast, the long-run adjustment following a positive uncertainty shock exceeds that following a negative shock for the Fine Wine 50. A 1\% increase in EPU is predicted to decrease the Fine Wine 50 by $0.45 \%$ and the Fine Wine 100 by $0.62 \%$. Likewise, a $1 \%$ decrease in EPU is predicted to increase the Fine Wine 50 by $0.16 \%$ and the Fine Wine 100 by $0.86 \%$.

Table 5 describes the short- and long-run asymmetric dynamic interactions of fine wine prices with BC. Regarding the short-run symmetry, shocks in Europe have a significant positive impact on the Fine Wine 50 (0.5510) and Fine Wine Investables (0.3062). Consistent with the Wald test, the three fine wine indices have short-run asymmetric adjustments to BC shocks. All three fine wine indices have positive adjustments to both negative and positive shocks. American shocks induce adjustments in all fine wine indices. In addition, the Fine Wine 50 also has adjustments to Chinese shocks and the Fine Wine 100 has adjustments to European shocks. Surprisingly, the Fine Wine 100 has positive lag 1 adjustments to negative shocks (3.1046) with negative lag 0 adjustments $(-0.9568)$.

We observe that the long-run symmetry is positive and significant between the Fine Wine 50 and China and Europe, as well as between the Fine Wine Investables and China. The reported impacts $L^{+}\left(L^{-}\right)$of positive (negative) uncertainty shocks are negative and significant between Europe and the Fine Wine 100 and positive between China and the Fine Wine 100. The long-run adjustments following negative uncertainty shocks exceed those following positive shocks. A $1 \%$ increase in European EPU is predicted to decrease the Fine Wine 100 by $0.38 \%$, while a $1 \%$ decrease is predicted to decrease it by $0.65 \%$. A $1 \%$ increase in Chinese EPU is predicted to increase the Fine Wine 100 by $0.24 \%$, while a $1 \%$ decrease is predicted to increase it by $0.25 \%$.

\section{Discussion}

Fine wine is a global market which involves many stakeholders, from producers to resellers, middlemen, wholesalers, and investors. All are interested in price forecasting to allow them to implement fine-tuned strategies, both in the primary and the secondary markets. ${ }^{5}$ In this paper, we mainly focus on economic agents involved in the secondary market, such as investors, wineries, and merchants.

As an alternative investment asset, fine wines offer interesting opportunities, with low risk and relatively large returns (Masset \& Henderson, 2010; see Le Fur and Outreville for a review of the literature), but also specific costs (storage and insurance costs, transaction costs related to auction houses or to bargain issues with intermediaries...). This investment is also subject to double taxation: on imports, as a tangible product; and on economic gains, as an investment asset. These additional costs could significantly affect the profitability of some investment schemes, as well as the price and demand for one or other wine references.

\footnotetext{
5 While the primary market could be defined as the traditional B2C market, from producers to consumers, the secondary market is a speculative B2B market and exclusively concerns fine wines because of their unique properties (scarcity, taste-related qualities, ageing potential...).
} 


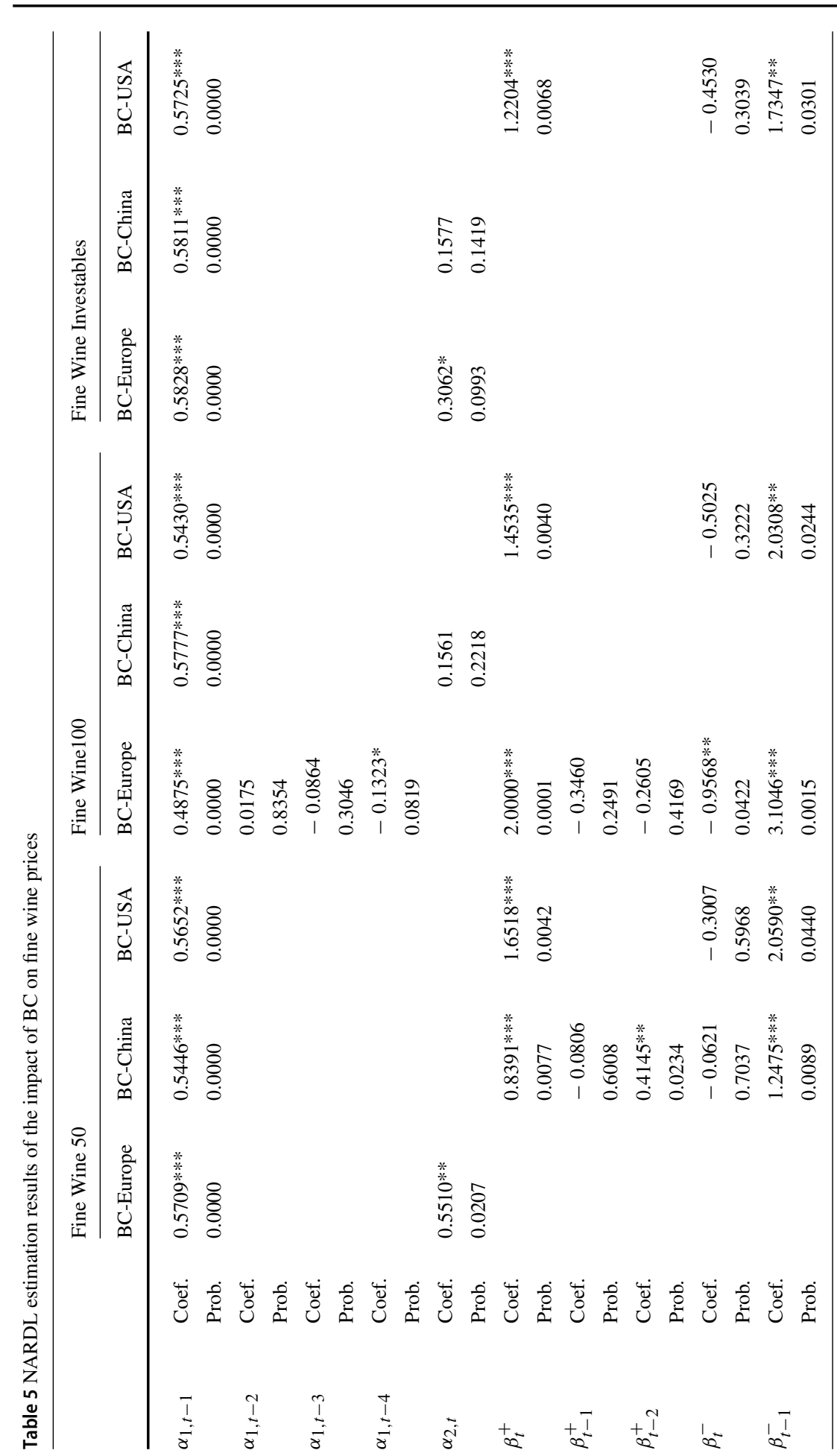




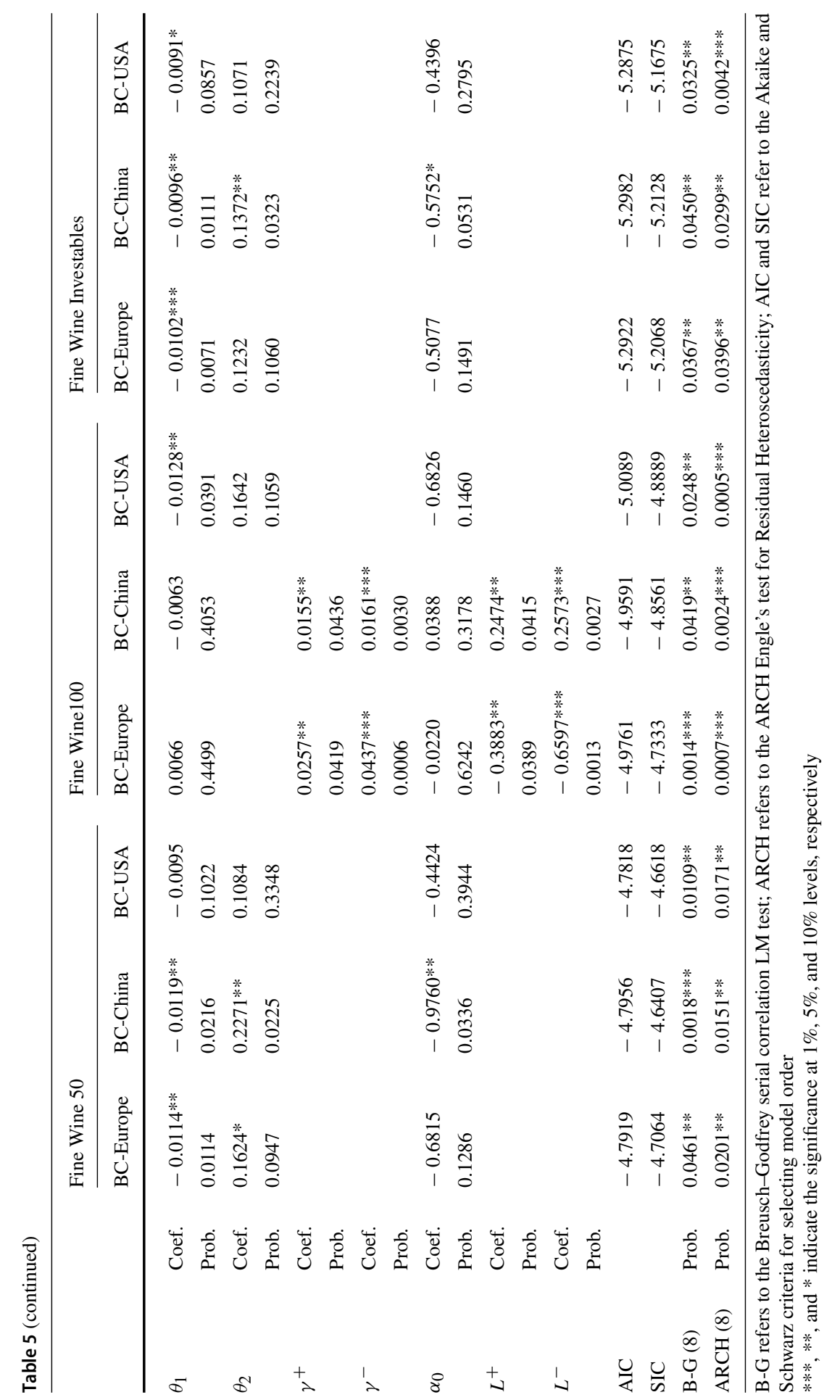


Importantly, uncertainty over tariff and policy changes can affect the prices of fine wine. Our paper thus analyzes how uncertainties flowing from economic policy decisions impact fine wine prices. This analysis is even more important given the changing geopolitical context. Following years of multilateralism, the global trading system is now "narrowing". Bilateral treaties appear to gradually be replacing multilateral free-trade agreements, and governments seem less reluctant to enforce protectionist measures. Brexit also signals a sort of deglobalization trend, with less integrated economies.

The wine market is increasingly affected by policy uncertainties and specific rules likely to affect EPU. For instance, in 2021, legislation in Russia decreed that only local producers could now use the "shampanskoye" name (the Russian equivalent of champagne), leading a number of French houses to suspend deliveries to Russia (The Guardian, $2021^{6}$ ). It is too early to assess the impact of such an unexpected and unilateral decision on Champagne prices as yet. However, previous policy decisions have already shown their capacity to affect fine wine prices. This was the case in 2019 when the Trump administration engaged the USA in a wine trade war against the EU that impacted fine wine prices in the secondary market (New York Times, 20197 ). It was also the case in 2017 when Japan and the EU entered into negotiations for a freetrade agreement, finally signed in 2019. According to Anderson and Wittwer (2017, 2018), Brexit will also have a long-term impact on the secondary market. Moreover, as Shankar and Francis (2021) reported, Brexit has already generated some practical consequences, with some famous French wineries-expecting advantageous interest rate fluctuations - deciding to withhold their stocks in order to sell their wines later at a premium. Lastly, the 2008 financial crisis affected both supply and demand in the Bordeaux wine market: wineries were forced to cut their prices in order to remain attractive for cautious investors (WineCellarInsider, 2010 ${ }^{8}$ ).

Our findings help the wine industry stakeholders to understand how EPU and economic cycles affect fine wine prices. On the one hand, we show that fine wine prices are more reactive to business cycles than to uncertainties in the short run. On the other hand, we find that uncertainty in Europe and the USA affects fine wine prices more than uncertainty in China. We suggest that a strong and professional strategic intelligence watch would help stakeholders in the secondary wine market to improve their returns, especially when European and US wines are involved. While short runners should focus on information relative to changes in the business cycle, long-term investors would be better off closely monitoring policy decisions liable to have longterm effects on wine prices (such as taxation, monetary measures, etc.).

Such investor-specific recommendations usefully complement the policy implications for the wine industry identified by Shankar and Francis (2021). In addition, our findings largely confirm their key results and strategic advice for wineries. We provide insights into how monitoring EPU can help wine producers to improve their results by giving productive answers to strategic questions, such as which geographic market to

\footnotetext{
6 https://www.theguardian.com/world/2021/jul/05/shampanskoye-french-champagne-industry-in-a-fizzover-russian-law.

7 https://www.nytimes.com/2019/04/09/us/politics/boeing-airbus-tariffs.html.

8 https://www.thewinecellarinsider.com/wine-topics/the-roller-coaster-win-market/.
} 
prioritize, how distribution channels should be subsequently adapted, how to manage stocks efficiently, and whether it is worth cutting prices or diversifying a client base when an increase is expected in the EPU level.

\section{Conclusion}

Using economic policy uncertainty and the consumer price index, we examined the link between three main regional economies, China, Europe, and the USA, and the prices of three fine wine indices widely used by investors as benchmarks. In other words, we studied the effects resulting from the uncertainty of a drop in consumption and government policies on fine wines in these three economies over the period 2005-2020. We adopted the NARDL model that allowed the observation of short- and long-run asymmetric effects between both EPU and BC and fine wine prices.

Our results indicate that uncertainty asymmetrically affects the prices of fine wines relatively little. On the other hand, the business cycle has a more pronounced asymmetric effect in the short run on the price of fine wines. Europe and the USA have a greater impact on fine wine prices than China. The prices of the five first growths of Bordeaux are more asymmetrically impacted than the most prestigious Bordeaux wines, which are hardly affected at all. Finally, fine wine prices react more strongly to changes in business cycles than to uncertainty in the short run.

Our paper has implications for several actors such as investors (both individual and institutional), collectors, traders and brokers. Indeed, clear knowledge of the influence of uncertainty and the business cycle on the price of fine wines could help them to better assess their arbitrage and the management of portfolios containing this asset. We suggest three possible avenues for future research. One research avenue concerns the role of asymmetry during recent crises such as the subprime mortgage crisis, the 2012 crisis, Brexit, and the COVID-19 pandemic. This extension would provide more insights into the impact of these crises on the price of fine wines. A second research avenue concerns analysis of asymmetry in the prices of the most desirable wines in international auctions. This ground-breaking study would provide investors and collectors with a better understanding of the factors affecting the prices of fine wines. Determining fine wine returns through a better understanding of uncertainty and business cycles could also provide an avenue for further research, as could the role of asymmetry in macroeconomic contagion or transmission of volatility. Finally, it would be useful to analyze the consequences of these two parameters in financial and behavioral management terms with respect to the portfolio management of investors, collectors, and traders.

\section{References}

Amédée-Manesme, C. O., Faye, B., \& Le Fur, E. (2020). Heterogeneity and fine wine prices: Application of the quantile regression approach. Applied Economics, 52(26), 2821-2840.

Anderson, K., \& Wittwer, G. (2013). Modeling global wine markets to 2018: Exchange rates, taste changes, and China's import growth. Journal of Wine Economics, 8(2), 131-158. 
Anderson, K., \& Wittwer, G. (2017). U.K. and global wine markets by 2025n and implications of Brexit. Journal of Wine Economics, 12(3), 221-251.

Anderson, K., \& Wittwer, G. (2018). Cumulative effects of Brexit and other UK and EU-27 bilateral freetrade agreements on the world's wine markets. The World Economy, 41(11), 2883-2894.

Antonakakis, N., Gupta, R., \& André, C. (2015). Dynamic co-movements between economic policy uncertainty and housing market returns. Journal of Real Estate Portfolio Management, 21(1), 53-60.

Ashenfelter, O. (2008). Predicting the quality and prices of bordeaux wine. The Economic Journal, 118(529), $174-184$.

Aytaç, B., \& Mandou, C. (2016). Wine: To drink or invest in? A study of wine as an investment asset in French portfolios. Research in International Business and Finance, 36, 591-614.

Baker, S. R., Bloom, N., \& Davis, S. J. (2016). Measuring economic policy uncertainty. The Quarterly Journal of Economics, 131(4), 1593-1636.

Balcilar, M., Bekiros, S., \& Gupta, R. (2017). The role of news-based uncertainty indices in predicting oil markets: A hybrid nonparametric quantile causality method. Empirical Economics, 53(3), 879-889.

Baumol, W. J. (1986). Unnatural value: Or art investment as floating crap game. The American Economic Review, 76(2), 10-14.

Ben Ameur, H., \& Le Fur, E. (2020). Volatility transmission to the fine wine market. Economic Modelling, $85,307-316$.

Bouri, I. (2014). Beyond the negative relation between return and conditional volatility in the wine market: Is fine wine particularly luscious for investors? International Journal of Wine Business Research, 26(4), 279-294.

Brogaard, J., \& Detzel, A. (2015). The asset pricing implications of government economic policy uncertainty. Management Science, 61(1), 3-18.

Burton, B. J., \& Jacobsen, J. P. (1999). Measuring returns on investments in collectibles. Journal of Economic Perspectives, 13(4), 193-212.

Cardebat, J. M., Faye, B., Le Fur, E. \& Masset, P. (2020). Attributes' specification of wine indexes: is devil in the details?. Bankers, Markets \& Investors, 161.

Cardebat, J. M., \& Figuet, J. M. (2019). The impact of exchange rates on French wine exports. Journal of Wine Economics, 14(1), 71-89.

Chu, P. K. K. (2014). Study on the diversification ability of fine wine investment. The Journal of Investing, 23(1), 123-139.

Coffman, B. A., \& Nance, R. J. (2009). Wine: The Illiquid Liquid Investment Asset. Journal of Financial Planning, 22(12).

Dickey, D. A., \& Fuller, W. A. (1979). Distribution of the estimators for autoregressive time series with a unitroot. Journal of the American statistical association, 74(366a), 427-431.

Dagenais, M. G. (1994). Parameter estimation in regression models with errors in the variables and autocorrelated disturbances. Journal of Econometrics, 64(1-2), 145-163.

Dimson, E., Rousseau, P. L., \& Spaenjers, C. (2015). The price of wine. Journal of Financial Economics, $118(2), 431-449$.

Faye, B., Le Fur, E., \& Prat, S. (2015). Dynamics of fine wine and asset prices: Evidence from short-and long-run co-movements. Applied Economics, 47(29), 3059-3077.

Fogarty, J. J. (2010). Wine investment and portfolio diversification gains. Journal of Wine Economics, 5(1), $119-131$.

Hekimoglu, M. H., Kazaz, B., \& Webster, S. (2017). Wine analytics: Fine wine pricing and selection under weather and marketuncertainty. Manufacturing \& Service Operations Management, 19(2), 202-215.

Haug, A. A. (2002). Temporal aggregation and the power of cointegration tests: A Monte Carlo study. Oxford Bulletin of Economics and Statistics, 64, 399-412.

Jaeger, E. (1981). To save or savor: The rate of return to storing wine. Journal of Political Economy, 89(3), 584-592.

Jiao, L. (2017). Macroeconomic determinants of wine prices. International Journal of Wine Business Research, 29(3), 234-250.

Jones, A. T., \& Sackley, W. H. (2016). An uncertain suggestion for gold-pricing models: The effect of economic policy uncertainty on gold prices. Journal of Economics and Finance, 40(2), 367-379.

King, R. G., Plosser, C. I., \& Rebelo, S. T. (2002). Production, growth and business cycles: Technical appendix. Computational Economics, 20(1), 87-116.

Kourtis, A., Markellos, R. N., \& Psychoyios, D. (2012). Wine price risk management: International diversification and derivative instruments. International Review of Financial Analysis, 22, 30-37. 
Krasker, W. S. (1979). The rate of return to storing wines. Journal of Political Economy, 87(6), 1363-1367.

Le Fur, E. (2018). The long-term relationship between the classic cars market prices and financial markets. Bankers, Markets and Investors, 152.

Le Fur, E. (2020). Dynamics of the global fine art market prices. The Quarterly Review of Economics and Finance, 76, 167-180.

Le Fur, E. (2021a). Collectors' motives in the context of wealth management. Journal of Asset Management, $1-12$.

Le Fur, E. (2021b). Contagion effect between financial markets and collectibles markets: A review of empirical research. FINANCIALAND ECONOMIC SYSTEMS: Transformations and New Challenges, $135-159$.

Le Fur, E., Ameur, H. B., \& Faye, B. (2016). Time-varying risk premiums in the framework of wine investment. Journal of Wine Economics, 11(3), 355.

Le Fur, E., \& Outreville, J. F. (2019). Fine wine returns: A review of the literature. Journal of Asset Management, 20(3), 196-214.

Lolić, I., Sorić, P., \& Logarušić, M. (2021). Economic policy uncertainty index meets ensemble learning. Computational Economics, 1-37.

Masset, P., \& Henderson, C. (2010). Wine as an alternative asset class. Journal of Wine Economics, 5(1), $87-118$.

Masset, P., Weisskopf, J. P., Cardebat, J. M., Faye, B., \& Le Fur, E. (2021). Analyzing the risks of an illiquid and global asset: The case of fine wine. The Quarterly Review of Economics and Finance, 82, 1-25.

Masset, P., Weisskopf, J. P., Faye, B., \& Le Fur, E. (2016). Red obsession: The ascent of fine wine in China. Emerging Markets Review, 29, 200-225.

Masset, P., \& Weisskopf, J. P. (2018). Raise your glass: Wine investment and the financial crisis (pp. 271-296). World Scientific Publishing Company.

Noparumpa, T., Kazaz, B., \& Webster, S. (2015). Wine futures and advance selling under quality uncertainty. Manufacturing and Service Operations Management, 17(3), 411-426.

Outreville, J.F., \& Le Fur, E. (2020). Hedonic Price Functions and Wine Price Determinants: A Review of Empirical Research. Journal of Agricultural \& Food Industrial Organization, 18(2).

Phillips, P. C., \& Perron, P. (1988). Testing for a unit root in time series regression. Biometrika, 75(2), 335-346.

Sanning, L. W., Shaffer, S., \& Sharratt, J. M. (2008). Bordeaux wine as a financial investment. Journal of Wine Economics, 3(1), 51-71.

Satchell, S. (Ed.). (2009). Collectible Investments for the High Net Worth Investor. Academic Press.

Shankar, N., \& Francis, B. (2020). Economic policy uncertainty and fine wine prices. International Journal of Wine Business Research, 32(3), 457-476.

Shankar, N., \& Francis, B. (2020). Economic policy uncertainty and fine wine prices. International Journal of Wine Business Research.

Shin, Y., Yu, B., Greenwood-Nimmo, M. (2014). "Modelling asymmetric cointegration and dynamic multipliers in a nonlinear ARDL framework", In The Festschrift in Honor of Peter Schmidt.: Econometric Methods and Applications; Horrace, W., Sickles, R., Eds.; Springer: New York, NY, USA, pp. 281-314.

Storchmann, K. (2012). Wine economics. Journal of Wine Economics, 7(1), 1-33.

Publisher's Note Springer Nature remains neutral with regard to jurisdictional claims in published maps and institutional affiliations. 